NBER WORKING PAPER SERIES

FIVE CENTURIES OF LATIN AMERICAN INEQUALITY

\author{
Jeffrey G. Williamson \\ Working Paper 15305 \\ http://www.nber.org/papers/w15305 \\ NATIONAL BUREAU OF ECONOMIC RESEARCH \\ 1050 Massachusetts Avenue \\ Cambridge, MA 02138 \\ August 2009
}

This paper is a revision of "History without Evidence: Latin American Inequality since 1491" presented to the conference on A Comparative Approach to Inequality and Development: Latin America and Europe (Madrid: May 8-9, 2009) and to the Inequality Session of the World Economic History Congress (Utrecht: August 3-7, 2009). I acknowledge with gratitude: comments on the paper and previous discussions on the topic with Daron Acemoglu, Bob Allen, Lety Arroyo Abad, Carlos Bazdresch, Luis Bértola, John Coatsworth, Rafa Dobado, Regina Grafe, Alejandra Irigoin, Peter Lindert, Branko Milanovic, Leandro Prados de la Escosura, Jaime Salgado, Dick Salvucci, Blanca Sánchez-Alonso, Sam Williamson and participants at seminars at CIDE (October 2007), Canterbury (March 2009), ANU RSSS-Economics (April 2008), Warwick (May 2008), Paris GlobalEuronet Summer School (July 2008), Barcelona (October 2008), IISH (October 2008), the Wisconsin AE Development Workshop (October 2008), and the Michigan Development/History Workshop (December 2008); and, especially, generous help with the data from Amilcar Challu. The views expressed herein are those of the author(s) and do not necessarily reflect the views of the National Bureau of Economic Research.

NBER working papers are circulated for discussion and comment purposes. They have not been peerreviewed or been subject to the review by the NBER Board of Directors that accompanies official NBER publications.

(C) 2009 by Jeffrey G. Williamson. All rights reserved. Short sections of text, not to exceed two paragraphs, may be quoted without explicit permission provided that full credit, including $\odot$ notice, is given to the source. 
Five Centuries of Latin American Inequality

Jeffrey G. Williamson

NBER Working Paper No. 15305

August 2009

JEL No. D31,N16,O54

\begin{abstract}
$\underline{\text { ABSTRACT }}$
Most analysts of the modern Latin American economy hold to a pessimistic belief in historical persistence -- they believe that Latin America has always had very high levels of inequality, suggesting it will be hard for modern social policy to create a more egalitarian society. This paper argues that this conclusion is not supported by what little evidence we have. The persistence view is based on an historical literature which has made little or no effort to be comparative. Modern analysts see a more unequal Latin America compared with Asia and the rich post-industrial nations and then assume that this must always have been true. Indeed, some have argued that high inequality appeared very early in the post-conquest Americas, and that this fact supported rent-seeking and anti-growth institutions which help explain the disappointing growth performance we observe there even today. This paper argues to the contrary. Compared with the rest of the world, inequality was not high in pre-conquest 1491, nor was it high in the post-conquest decades following 1492. Indeed, it was not even high in the mid-19th century just prior Latin America's belle époque. It only became high thereafter. Historical persistence in Latin American inequality is a myth.
\end{abstract}

Jeffrey G. Williamson

The University of Wisconsin

350 South Hamilton Street \#1002

Madison, WI 53703

and Harvard University and CEPR

and also NBER

jwilliam@fas.harvard.edu 


\section{Latin American Inequality over Five Centuries}

Most analysts of the modern Latin American economy carry a pessimistic belief in historical persistence: that is, they believe that Latin America has always had very high levels of income and wealth inequality, suggesting it will be hard, or even impossible, for modern social policy to create a more egalitarian society. This paper argues that this conclusion is not supported by what little evidence we have. The persistence view is based on an historical literature which has made little or no effort to be comparative. Indeed, other studies have shown that even where there is measured historical persistence, the effects decay over time (Banerjee and Iyer 2005; Nunn 2008; Bruhn and Gallego 2009). Yet modern analysts see a more unequal Latin America compared with Asia and the rich post-industrial nations (López and Perry 2008) and then assume that this must always have been true. Indeed, some have argued that high inequality appeared very early in the post-conquest Americas, and that this fact supported rent-seeking and anti-growth institutions which help explain the disappointing growth performance we observe there even today. This paper argues to the contrary. Compared with the rest of the world, inequality was not high in pre-conquest 1491, nor was it high in the postconquest decades following 1492 . Indeed, it was not even high in the mid-1 $9^{\text {th }}$ century just prior Latin America’s belle époque. It only became high thereafter. Historical persistence in Latin American inequality is a myth.

The next section places Latin American pre-industrial inequality in context by comparing it with inequality the world around over the two millennia from Rome in 14 AD to British India in 1947. It turns out that there is little that is unusual about pre- 
industrial Latin America when that comparison is made. The paper then offers empirical explanations for pre-industrial inequality the world around over the two millennia since Rome, including late $18^{\text {th }}$ and $19^{\text {th }}$ century Latin America. Next, we ask whether Latin America has always been more unequal. The paper goes on to use the estimated relationship found in the pre-industrial sample to fill by prediction the many and big empirical gaps in Latin American inequality history from 1491 through the end of the belle époque. That is, it uses an estimated world pre-industrial relationship to predict Latin American inequality where no income distribution evidence is yet available. These predictions are then compared with the Latin American inequality facts where they exist. The paper concludes by posing four revisionist hypotheses. The hope is that these working hypotheses will be used to motivate the collection of new pre-industrial inequality evidence and thus perhaps to overthrow once and for all the historical persistence view that pervades modern debate about Latin American inequality.

\section{Latin America in Context: What Did Pre-Industrial Inequality Look Like the World Round? ${ }^{1}$}

We have no evidence documenting inequality for the Inca, Aztec or other indigenous civilizations in the Americas prior to the arrival of the Iberian conquerors. But we can guess. Recently, Branko Milanovic, Peter Lindert and myself (2008; hereafter BMW) collected what we call an 'ancient inequality' data base for 29 places, ranging over two millennia from the Roman Empire in the year 14, Byzantium in the year 1000, England in 1290, Tuscany in 1427, Holland in 1732, Old Castille in 1752, France in 1788, Java in 1880, and British India in 1947. The sample includes four Latin American

\footnotetext{
${ }^{1}$ As will be apparent, this and the next section draw heavily on Milanovic et al. (2008).
} 
observations: Nueva España 1790, Chile 1861, Brazil 1872, and Peru 1876, although a new Mexican 1844 social table observation can now be added to the BMW sample. While each of these 29 BMW observations reports a Gini coefficient and other measures of inequality, only Tuscany 1427 offers a full size distribution of income. Instead, the observations have been constructed mainly from what are called social tables, sources which report average income and income recipients by social classes, but no income variance within them.

Social tables are particularly useful in evaluating ancient societies where classes were clearly delineated, where the differences in mean incomes between them were substantial, and where mobility between them was trivial. If class (and race) alone determined one's income, and if income differences between classes were large while income differences within classes were small (mainly reflecting life-cycle status and luck), then most inequality would be explained by average income differences between classes. One of the most famous social tables was constructed by Gregory King for England and Wales in 1688 (Barnett 1936; Lindert and Williamson 1982). King's class list was fairly detailed (31 in number), but he did not report inequalities within these social groups, so we cannot identify within-class inequality for 1688 England. Yet, when income variance within class is also available for any pre-industrial country offering social table estimates, the differences between measured inequality are typically very small whether within class variance is included or excluded. Indeed, when comparing any two pre-industrial societies where full size distributions are available, inequality differences between them can be explained almost entirely by inequality differences measured by class differences alone. In short, the lion's share of inequality in pre- 
industrial societies is and was accounted for by between-class average income

differences.

Table 1 and Figure 1 report what these BMW data look like. The Gini estimates are plotted in Figure 1 against income or GDP (or GDI) per capita. Figure 1 also displays what we call the inequality possibility frontier (solid line), a curve based on the maximum inequality the elite could have extracted at that income per capita. The maximum is constructed under the assumption that everybody but the elite in such repressive societies would have gotten just the World Bank's subsistence minimum of \$PPP $300 .{ }^{2}$ The ratio of the actual inequality to the maximum feasible inequality (both expressed in Gini coefficients) is called the extraction ratio. ${ }^{3}$ In most cases, the calculated pre-industrial Ginis lie pretty close to the inequality possibility frontier (IPF). The countries farthest below the IPF curve - with the lowest extraction ratios -- are the most advanced pre-industrial economies in northwestern Europe: that is, 1561-1808 Holland, 1788 France, and 1688-1801 England.

The inequality possibility frontier allows us to better situate these ancient preindustrial inequality estimates in a modern context. The bottom panel of Table 1 provides estimates of inequality extraction ratios for 25 contemporary societies. Brazil has often

\footnotetext{
${ }^{2}$ This is less than Maddison's (1998: 12) assumed subsistence minimum of \$PPP 400 which, in principle, covers more than physiological needs. Note that a purely physiological minimum "sufficient to sustain life with moderate activity and zero consumption of other goods" (Bairoch 1993: 106) was estimated by Bairoch to be \$PPP 80 at 1960 prices, or \$PPP 355 at 1990 prices. Our minimum is also consistent with the World Bank absolute poverty line which is 1.08 per day per capita in 1993 \$PPP (Chen and Ravallion 2007: 6). This works out to be about \$PPP 365 per annum in 1990 international prices. Since more than a billion people are believed to have incomes less than the World Bank global poverty line, it seems reasonable to assume that the physiological minimum income must be less. One may recall also that Colin Clark (1957: 18-23) distinguished between international units (the early PPP dollar) and oriental units, the lower dollar equivalents which he thought held for subtropical or tropical regions where calorie, housing and clothing needs are considerably less than those in temperate climates. Since our ancient pre-industrial sample includes a fair number of tropical countries, this gives us another reason to use a conservatively low estimate of the physiological minimum.

${ }^{3}$ The extraction ratio is not unlike an index of the percent in poverty, but where the poverty line is fixed.
} 
been cited as an example of an extremely unequal society, driven by a long history of slavery, racial discrimination and regional dualism. Indeed, Brazil's Gini in 2002 is comparable to the most unequal pre-industrial societies in our ancient inequality sample. But Brazil is more than four times richer than the average ancient society in our sample, so its maximum feasible inequality (92.7) is much higher than our ancient society average (60.6). Thus, modern elites have extracted only a little more than 63 percent of the maximum feasible inequality in Brazil, and its inequality extraction ratio is about the same as what we find among the least exploitative and repressive ancient societies like 1801-3 England and 1886 Japan. What is true of Brazil, is also true of contemporary Chile, Mexico and Peru. All three have Ginis today well above the world average (Chile $2003=54.6$, Mexico $2000=53.8$ and Peru $2002=52$ versus the world average $=40.6$ ), but all three have extraction ratios below the least exploitative in our ancient societies sample. Furthermore, not all of these four have Ginis today above what they were 150200 years ago. Inequality has fallen over two centuries in two Latin American republics for which data exist: Chile $1861=63.7$ to $2003=54.6$, or 14 percent lower, and Mexico $1790=63.5$ to $2000=53.8$, or 15 percent lower. Inequality has been on the rise over two centuries in the other two Latin American republics for which data exist: Brazil $1872=$ 43.3 to $2002=58.8$, or 36 percent higher; and Peru $1876=42.2$ to $2002=52$, or 23 percent higher.

As a country becomes richer, and its surplus above subsistence rises, its feasible inequality expands. Consequently, even if recorded inequality is stable, the extraction ratio must fall. This can be seen in Figure 2 where the inequality extraction ratio is plotted against income per capita for both ancient societies and their modern 
counterparts. Thus, the social consequences of increased inequality may not entail as much relative impoverishment, or as much perceived injustice, as might appear if we looked only at the recorded Gini. This logic is particularly compelling for low and middle-income societies where increases in income push the maximum feasible inequality up sharply along the steepest part of the IPF curve. The farther a society rises above the subsistence minimum, the less will economic development lift its inequality possibilities, and thus the extraction ratio will be driven more and more by the rise in the actual Gini itself. Thus, the inequality extraction ratio has fallen everywhere in Latin America over the past century or two, and in some cases by a lot: it has fallen by 15 percent in Brazil (from 74.2 in 1872 to 63.4 in 2002), by 32 percent in Chile (from 83 in 1861 to 56.4 in 2003), by 47 percent in Mexico (from 105.5 in 1790 to 56.2 in 2000), and by 27 percent in Peru (from 78.1 in 1876 to 56.7 in 2002). While the rest of this paper will focus on actual or measured inequality, future debates over social justice and economic development will have to struggle with the implications of different trends in actual inequality and extraction ratios.

\section{Fundamentals: Explaining Pre-Industrial Inequality the World Round}

Using this BMW information from ancient pre-industrial societies, can we explain differences in observed inequality? The Kuznets hypothesis posits that inequality tends to follow a bell-shape as average real income increases. Although Kuznets formulated his hypothesis explicitly with a view toward industrializing and industrialized economies, one might wonder whether his Curve is even more apparent among our pre-industrial 
economies as well. After all, the secular upswing could be easily explained by increases in per capita income: poor countries do not have much surplus for the elite to extract, but as income rises in pre-industrial economies, so does the surplus and potential inequality. In addition to $\log$ average income and its square, Table 2 includes the urbanization rate, population density and colonial status (a dummy variable). The regression also includes a number of controls for country-specific eccentricities in the data: the number of social groups available for calculating the Gini, whether the social table is based on tax data, and whether the social table for a colony includes the income of resident colonists. The Kuznets hypothesis predicts a positive coefficient on average income (or its log) and negative coefficient on its square. We also expect higher inequality for the more urbanized countries (reflecting a common finding that inequality in urban areas tends to be higher than in rural areas: Ravallion et al. 2007), and for those that are ruled by foreign elites since powerful colonizers are presumed to be able to achieve higher extraction rates than weaker local elites, and since countries with weak local elites but with large surpluses will attract powerful colonizers to extract it (Acemoglu, Johnson and Robinson 2001, 2002).

The empirical results confirm all expectations. Both income terms are of the right sign and significant, supporting a pre-industrial Kuznets Curve. ${ }^{4}$ The sign on the urbanization rate is, as predicted, positive, but since it competes with population density, its statistical significance is somewhat lower. Still, each percentage point increase in the urbanization rate (say, from 10 percent to 11 percent) is associated with an increase in the Gini by 0.35 points. Colonies were clearly much more unequal: holding everything else

\footnotetext{
${ }^{4}$ Note that GDP per capita is in natural logs.
} 
constant, colonies had a Gini almost 13 points higher than non-colonies. ${ }^{5}$ Foreigner is a dummy variable that controls for two observations (South Serbia 1455 and Levant 1596) that were colonies but where their ancient inequality surveys did not report the incomes and numbers of colonizers at the top. This is therefore simply another control for data eccentricity, and its negative sign shows that being a colony, but not having colonizers included in the survey, reduces recorded inequality considerably ( 9 to 10 points).

The number of social groups used in the inequality calculations, or tax census origin of social tables, do not affect the Gini in any significant way. This finding is comforting, especially regarding Nueva España's three classes, because it shows that our estimates of inequality are being driven by fundamentals, not by the way the social tables were constructed by pre-industrial observers.

Population density is negatively associated with inequality, although its significance weakens when the two Java observations - the most dense part of the preindustrial world - are removed. It might have been expected that the introduction of a dummy variable for more densely populated Asia would have caused the effect of density to dissipate. This is not the case, as shown in column 2 of Table 2 . The negative impact of population density on inequality seems to be counter-intuitive. After all, conventional theory - which we will exploit below -- would predict that more population pressure on the land should raise land yields and rents, lower labor's marginal product and the wage, thus producing more inequality, not less. Furthermore, this effect should have been all the more powerful in pre-industrial societies where land and labor drove inequality not, as in modern societies, human capital and financial wealth. It seems likely that this

\footnotetext{
${ }^{5}$ To repeat, it should be stressed that this is a correlation only. The causal relation cannot be identified with this regression.
} 
conventional effect is being offset in the ancient economy data by two forces. First, densely populated agrarian societies also had lower per capita income, so this may have been working against the conventional force (since inequality rises with per capita income). Second, more densely populated agrarian societies must have had higher relative food prices than thinly settled societies, so that nominal subsistence had to be much higher to purchase the more expensive foodstuffs, lowering measured inequality and the extraction ratio. ${ }^{6}$ It seems likely that this force must have been most powerful during the two millennia before the middle of the $19^{\text {th }}$ century since a world market for grains did not yet exist and thus local conditions dictated the relative price of food (Latham and Neal 1983; Clingingsmith and Williamson 2008; Studer 2008). This second offset has important implications for comparing inequality in the labor-scarce and resource-abundant Americas with the labor-abundant and resource-scarce Europe, and between the densely populated highlands in Mexico and the Andes relative to resourceabundant Southern Cone. However, it is less clear that it had the same effect within countries over time, since the results in Table 2 rely almost entirely on a cross section, not a time series. Finally, to the extent that population size and density are correlated, there is a third possible offset. Looking at modern data, Filipe Campante and Quoc-Anh Do (2007) explain the negative correlation by the size of the potential revolutionary underclass concentrated around the capital thus posing a threat to the elite.

\footnotetext{
${ }^{6}$ Rarely do even modern inequality studies assess the impact of different class-specific cost-of-living trends on real inequality trends. We know this mattered hugely in early modern Europe (Hoffman et al. 2002), and we need to know whether it has also mattered at any time in Latin America since 1491. When Latin America underwent her commodity export boom during the belle époque, did the rise in food export prices in the Southern Cone serve to raise real inequality even more than nominal inequality? Did it have the opposite effect in Mexico, which imported cheap corn from the United States? And what about $20^{\text {th }}$ century Latin American food exporters when their terms of trade collapsed 1915-1940?
} 
The stylized picture that emerges is this: Inequality follows contours that are consistent with the Kuznets Curve hypothesis, a pre-industrial secular rise to a peak, followed by a fall during modern economic growth. It follows that most of the preindustrial Third World had probably reached very high levels of inequality by the early $19^{\text {th }}$ century before what is called the first global trade boom. However, the extraction ratio tends to fall as income increases, even during pre-industrial times. This fact would, of course, invite a European colonist to plunder where the potential surplus was big, but where the local elite had relaxed their extraction rate. We will return to this issue below.

\section{Has Latin America Always Been More Unequal?}

Has Latin America always been more unequal than other parts of the world, as implied by the recent work of Stanley Engerman and Kenneth Sokoloff (1997; Engerman, Haber and Sokoloff 2000)? Engerman and Sokoloff offered a hypothesis to account for Latin American growth underachievement during the two centuries following its independence. Their thesis begins with the plausible assertion that high levels of income inequality, and thus of political power, favor rich landlords and rent-seekers, and thus the development of institutions which are compatible with rent-seeking but incompatible with economic growth. Their thesis argues further that high levels of Latin American inequality have their roots in the natural resource endowments present when Iberia conquered and colonized the region five centuries ago. Exploitation of the native population and of imported African slaves, as well as their subsequent disenfranchisement, reinforced the development of institutions incompatible with growth. 
Engerman and Sokoloff had no difficulty collecting evidence which confirmed high inequality, disenfranchisement and lack of suffrage in Latin America compared with the United States. But what about comparisons with the rest of the world, and what about earlier? ${ }^{7}$ Oddly enough, neither the Engerman-Sokoloff team or its critics have confronted the thesis with inequality evidence for the economic leaders in northwest Europe at comparable pre-industrial stages; this is the comparison that matters, not with industrial United States.

Table 3 presents inequality information for pre-industrial western Europe (that is, prior to 1810) and for pre-industrial Latin America (that is, prior to 1880). For the former, we have observations from 1788 France, 1561 and 1732 Holland, and 1688, 1759 and 1801 England-Wales. For the latter, we have Nueva España 1790 and Mexico 1844 taken as an average, Chile 1861, Brazil 1872 and Peru 1876. Engerman and Sokoloff coined their hypothesis in terms of actual inequality. According to that criterion, their thesis must be soundly rejected. That is, the (population weighted) average Latin American Gini (47.5) was considerably lower than that of western Europe (52.9), not higher. ${ }^{8}$

Furthermore, the comparative inequality implications emerging for these social tables have been confirmed recently by Rafael Dobado and Hector Gracia using an inequality proxy - Maddison's real GDP per capita relative to their unskilled grain wage: according to their data, in 1820 Mexico, Bolivia and Colombia all had less inequality than did the

\footnotetext{
${ }^{7}$ John Coatsworth argues that the Engerman-Sokoloff thesis has not held up well to scrutiny: "what little quantitative evidence there is does not suggest that ownership of land, or other assets for that matter, was more concentrated in Latin America than in the United States" (Coatsworth 2008: 553). However, Coatsworth's survey of the land and wealth distribution estimates for Latin America (Coatsworth 2008: Table 2, 553) reveals that the first Latin America observations are for the province of Buenos Aires in 1820 and 1838 , and for Rio de Janeiro in 1830 . He is not able to report any colonial observations. See also Johnson and Frank (2006) and Gelman and Santilli (2006).

${ }^{8}$ If pre-industrial Mexican inequality is described best by the 1844 observation in Table 3, then this conclusion can be made even stronger.
} 
Netherlands, the United Kingdom and France, or even Portugal and Spain (Dobado and Garcia 2009: Figure 18).

It is not true that pre-industrial Latin America was more unequal than preindustrial northwest Europe. ${ }^{9}$ Thus, if inequality encouraged rent-seeking and discouraged growth in Latin America, it did it even more so in northwest Europe where the industrial revolution first started! Since we know that high inequality was consistent with industrial revolutions occurring in western Europe, it is unclear why it should be inconsistent with it in Latin America somewhat later. However, Latin America was poorer than northwest Europe, and poorer societies have a smaller surplus for the elite to extract. Thus, maximum feasible inequality was considerably lower and extraction rates were considerably higher in Latin America than in northwest Europe (Table 3). While measured inequality does not support the Engerman-Sokoloff thesis, the extraction rate does. ${ }^{10}$ The Engerman-Sokoloff team, their followers, and their critics all need to decide which of these inequality indicators matters for their hypothesis and why. To the extent that political power determines the extraction ratio, then Daron Acemoglu and James Robinson may be quite right in stressing political inequality rather than just economic inequality (Acemoglu et al. 2008; Acemoglu and Robinson 2006).

\footnotetext{
${ }^{9}$ See also the summaries on this point in Bértola et al. (2009: 5-6) and Bértola (2009). It should be added that has Asia not always been less unequal? Ancient Asia was not significantly less unequal when we control for other factors. Indeed, population density is sufficient to identify why ancient Asia had lower levels of inequality than the rest of the pre-industrial world.

${ }^{10}$ In this sense, Coatsworth may have been too quick to conclude, based on measured inequality, that "if colonial institutions constrained economic development, they did not do so until after the colonial era" (Coatsworth 2008: 11).
} 


\section{Broad Sweep: Reconstructing Latin American Inequality Trends since 1491}

\section{Initial Conditions: What Was Latin American Inequality Like in 1491?}

Table 4 and Figure 3 use the Gini regression equation (1) in Table 2 and estimates of the dependent variables also reported in Table 4 to predict Ginis for Latin America in 1491 before the arrival of the Iberians, shortly after the conquest (call it 1492), 1600, 1700, 1790, 1820 and 1870. Table 4 also predicts Ginis for Mexico in 1820 and 1870. In addition, the table reports predictions for the five Latin American cases where we also have actual inequality estimates: i.e. Nueva España 1790, Mexico 1844, Brazil 1872, Chile 1861 and Peru 1876. While the correlation between actual and predicted inequality

for those five cases is hardly perfect, it is positive and strongly significant $\left(\mathrm{R}^{2}=0.68\right)$, a comforting result.

Table 4 implies that the Gini coefficient in Latin America prior to the arrival of the Iberians was 22.5 , which would have made it the society with the lowest inequality in the pre-industrial world (or at least in our sample of it: Table 1). China in 1880 had a Gini of 24.5, very close to pre-conquest Latin America. Dutch colonial Java had a Gini in 1880 of 39.7 , a figure which would have been 27.1 without the Dutch colonists (according to the BMW regression, 39.7-12.6 = 27.1). Thus, Table 4 implies that preconquest Latin America had modest levels of inequality much like all the other poor preindustrial societies in our sample which had escaped being colonized. 


\section{Extracting the Surplus: What Was the Colonial Impact Like after 1492?}

Given what we know about ancient pre-industrial economies the world around, and assuming that Iberian colonists were no better or worse at extracting surplus than were the other colonizers in the ancient inequality sample (England, Holland, and the Ottoman Turks), the answer to this question is quite simple. Colonies had higher Gini coefficients by 12-13 percentage points (Table 2), so the Latin American Gini coefficient might have drifted up from 22.5 in 1491 to something like 35 in the post-1492 decades. Perhaps it was in fact a bit lower or a bit higher, but inequality clearly must have jumped up significantly during the first decades after the Iberian conquest, an increase of about half. Not only did the Iberian elite replace the indigenous elite, but, if they were anything like the English, the Dutch and the Turks, the Iberians must have been able (or willing) to raise the extraction rate in their favor by a lot.

\section{Inequality Decline? The Likely Impact of the $16^{\text {th }}$ Century Demographic Disaster}

As is well known, European disease caused immense demographic damage to the indigenous population over the century following Columbus's first voyage, due to soaring mortality rates. Massimo Livi-Bacci thinks it shrank by more than 90 percent by the early $17^{\text {th }}$ century (Livi Bacci 2006). Other scholars, like Angus Maddison, think the shrinking was smaller, and Table 4 uses Maddison to take the lower bound. The Atlantic slave trade tried to substitute African slaves for decimated indigenous populations but their addition was far smaller than the subtraction from the indigenous population caused by European disease. Furthermore, the African slaves arrived in significant numbers only after a long lag. Moreover, not many were transported to the once densely populated 
highlands where the indigenous population losses were greatest, but rather to the sugarrich tropics where the losses were smallest. The demographic collapse destroyed indigenous political and institutional structures, facilitated religious and cultural assimilation, and helped raise the per capita income of the indigenous survivors who resettled on the best lands. ${ }^{11}$

It is useful to elaborate that last point: the demographic disaster in Latin America must have contributed to higher (but unknown) GDP per capita and average labor productivity, higher marginal productivity of labor, and lower marginal productivity of land, suggesting that the wage-rental ratio (w/r) went up and that inequality went down. The economics can be made a little more precise. Assume that only land (R) and labor (L) mattered in the early colonial economy, and that technology (A) was unchanged across the $16^{\text {th }}$ century. If we also assume constant returns to scale, then it follows that

$$
\begin{aligned}
& \mathrm{Y}=\mathrm{AR}^{\alpha} \mathrm{L}^{\beta}, \alpha+\beta=1, \\
& \mathrm{Y} / \mathrm{L}=\mathrm{A}(\mathrm{R} / \mathrm{L})^{\alpha}=\mathrm{y}=\mathrm{GDP} \text { per capita. }
\end{aligned}
$$

The marginal product of labor and land are, respectively,

$$
\mathrm{dY} / \mathrm{dL}=\beta(\mathrm{Y} / \mathrm{L})=\mathrm{w}, \mathrm{dY} / \mathrm{dR}=\alpha(\mathrm{Y} / \mathrm{R})=\mathrm{r}
$$

so that the wage-rental ratio is

$$
\mathrm{w} / \mathrm{r}=(\beta / \alpha)(\mathrm{R} / \mathrm{L})
$$

Thus, the wage-rental ratio rises with the land-labor ratio, and the elasticity relating the two is (under these assumptions) always 1.

\footnotetext{
${ }^{11}$ Bates, Coatsworth and Williamson (2007: 919-20). Note the demographic parallel with Alwyn Young's argument that today's HIV-AIDS raises the incomes of those Africans who survive the disease (Young 2005), or Joel Mokyr's argument that the Irish famine in the late 1840s raised per capita income of the survivors (Mokyr 1983).
} 
The elasticity of GDP per capita to the land-labor ratio is $\alpha$. Table 4 reports that population density fell by 51 percent between 1500 and 1600 (from 1.60 to 0.78 persons per square kilometer), implying that the land-labor ratio rose about 103 percent (from 0.63 to 1.28 square kilometers per person). If $\alpha=0.5$, then GDP per capita might have increased by about 52 percent over the century. John Coatsworth (2008: 548) is in agreement: "As European disease and abuse decimated indigenous populations ... per capita output rose ... Additional gains in productivity occurred when those who survived found work, resettled or were 'congregated' on the most productive lands." And what went up, then went down. As the indigenous population slowly recovered between 1600 and 1700, the land-labor ratio fell about 29 percent, implying that GDP per capita might have decreased by almost 15 percent, at least in the Latin American interior. Based on Mexican evidence, Coatsworth (2008: 548) thinks the fall was even bigger: "Mexican production stagnated for most of the seventeenth century, falling by half in per capita terms as population recovered ... The revival of the indigenous population ... put an end to rising productivity in agriculture." Of course, things were different in the sugar-based plantation islands of the Caribbean, but these crude estimates generated by land-labor ratio trends are used in Table 4 to interpolate GDP per capita between Maddison's observations for 1500 and 1790 .

According to the simple economics above, the percentage rise in the wage-rental ratio across the $16^{\text {th }}$ century would have been about the same as the percentage fall in the labor-land ratio. ${ }^{12}$ If population fell by Livi-Bacci's 90 percent estimate (from an index of

\footnotetext{
${ }^{12}$ The economics is very simple, and complexity would diminish the size of the demographic disaster effects estimated here, but not the direction. For example, if land supply was very elastic (as it probably was in the Americas) then the impact on the land-labor ratio would be diminished. To take another example, while the assumption of constant technology across the $16^{\text {th }}$ century is analytically convenient,
} 
100 to 10$)$, then the land-labor ratio rose by a factor of ten (from an index of 10 to 100$),{ }^{13}$ which implies that wage-rental ratio rose by a factor of 10 as well. As we noted above, and based instead on Maddison's population estimates, Table 4 implies that the landlabor ratio rose by more than 100 percent. We have assumed perfect competition in these calculations which, of course, is completely inconsistent with our knowledge that Iberian colonists introduced coercive and repressive devices so that labor's greater scarcity was not fully rewarded. In more formal terms, the Iberians used slavery, haciendas and other institutions to push the wage below labor's marginal product (Coatsworth 2008; Bértola et al. 2009: 6-8). Thus, the demographically-induced rise in the wage-rental ratio must have been considerably less than 100 percent. But even if it was only 25 or 50 percent, it implies pronounced downward pressure on inequality across the $16^{\text {th }}$ century. Furthermore, it seems likely that land concentration also diminished as labor got scarcer, so there are other reasons to believe that exogenous demographic trends put strong downward pressure on inequality across the $16^{\text {th }}$ century. On the other hand, improved productivity in extracting minerals from the mines as well as any general improvement in economy-wide productivity (e.g. a rise in A) might have pushed inequality in the opposite direction, upwards. What was the net effect? Table 4 predicts that after the initial effect of colonization, there was very little additional change in Latin American inequality up to 1600 .

technological transfer from Europe and mining development must have increased $A$ in the formal output and output per worker expression in the text. This point is expanded below.

${ }^{13}$ The cultivatable land area of Latin America was 10.966 million $\mathrm{km}^{2}$ between 1500 and 1800 . LiviBacci's 50 million pre-conquest population implies a population density of 4.56. His 3-4 (say 3.5) million estimate for c1700 implies a density of 0.31 , a spectacular fall of population density over the $16^{\text {th }}$ century. 


\section{Inequality Rise: What Did Latin American Inequality Look Like in 1790?}

Over the two centuries between 1600 and 1790, a number of fundamentals were at work in Latin America which would have served to raise inequality and extraction ratios. First and foremost, populations partially recovered their $16^{\text {th }}$ century losses. Interpolating 1790 from Maddison's (2008) estimates for 1700 and 1820, yields a rise in population from 8.6 million in 1600 to 12.45 million in 1790 . Thus, population density rose from about 0.78 to 1.14 , and land-labor ratios fell by about 31 percent. Second, GDP per capita rose from 438 to 650 , or almost by half, and urbanization rose from 9 to 14.2 percent, or by more than half. These forces imply that the Gini might have risen from 36.2 to 57.6, which, according to the Table 4 predictions, implies that over the three centuries between 1491 and 1870 Latin American inequality reached its peak in the late colonial decades just prior to independence.

\section{Revolution, Independence and Lost Decades}

While revolution, independence and the 'lost decades' that followed up to about 1870 (Bates, Coatsworth and Williamson 2007) were very complicated times, and while there must have been many forces at work influencing inequality, the ancient inequality regression predicts that the Gini probably dropped from 57.6 in 1790 to 46.4 in 1870 . The biggest force contributing to the fall was, of course, independence and de-colonization since the five 'lost decades' between the 1820 s and the 1870 yielded very little GDP per capita growth $^{14}$ or urbanization. Mexico repeats the Latin American (predicted) trends, its

\footnotetext{
${ }^{14}$ Debate over Angus Maddison's data is intense, but some adopt his more positive view of Latin American growth 1820-1870. See, for example, Leandro Prados de la Escosura (2007, 2009). However, even Prados' more rosy view of post-independence is consistent with very poor growth performance (Prados 2007: Table
} 
Gini falling from 57.7 to 44 between 1790 and 1870, and, once again, by far the biggest fall being between 1790 and 1820, from 57.7 to 47.8. Ongoing research by Amilcar Challu also suggests a significant fall in Mexican inequality: he estimates a social table for 1844 Querétaro yielding a Gini of 51.3, ${ }^{15}$ suggesting that most of the fall between 1790 and 1870 had taken place by the 1840 s.

Recent archival work by Leticia Arroyo Abad (2008: Figure 1) confirms this prediction of falling inequality after independence. She uses data on wage rates and land rents to infer trends in inequality. When her rent-wage ratios for Argentina, Mexico, and Venezuela are weighted by 1850 populations, the resulting Latin American rent-wage ratio falls by 11 percent $1820-1850$, and for Mexico alone the fall is 12 percent. Furthermore, the Arroyo Abad Mexican rent-wage ratio trends and the Mexican Gini coefficients coming from the social tables in Table 4 are closely reproduced by the Amilcar Challu rent-wage series for central Mexico 1780-1869 reported in Table 5. Challu's inequality index rises by 38 percent from the 1780 s to the 1800 s, falls by 29 percent from the 1800 s to the 1820 s, and then continues a slow downward drift during the 'lost decades' up to the 1860s. To summarize, the Arroyo Abad index falls by 4 percent per decade between 1820 and 1850, the Challu index falls by 5.2 percent per decade between 1820 and 1869, and our Gini in Table 4 falls by almost 2 percent per decade between 1820 and 1870 .

1.4): between 1820 and 1850, the two biggest republics, Brazil and Mexico, grew at 0 and 0.1 percent per annum, respectively; in the $1850 \mathrm{~s}$, the figures were -0.1 and -1.3 . Lost decades indeed.

${ }^{15}$ In personal correspondence, Challu has described Querétaro as quite representative, but it is, of course, only one state. 


\section{Creating Modern Inequality during the Belle Époque Globalization Boom}

"[As] export-led economic growth took off throughout Latin America in the late nineteenth century, economic inequality increased ... The returns to [land,] scarce capital and skills rose precipitously. Peasant and public lands ... passed into the hands of landlords, politicians, land companies and plantations ... The conditions that Engerman-Sokoloff and Acemoglu, Johnson, and Robinson saw as blocking economic growth were in fact the conditions that made it possible" (Coatsworth 2008: 567-8).

The economics underlying Coatsworth's statement above is, of course, quite straight forward. Latin America faced a rising terms of trade throughout the late $19^{\text {th }}$ century. Since it was a primary product exporter, land and mineral rents were driven up relative to wages. This happened everywhere around the poor periphery (Williamson 2002, 2008), but it was especially dramatic in Latin America partly because the region was able to expand its export sectors so effectively, thus to become very large shares in GDP (Williamson 2009: Table 4.1). Since land and mineral resources were held by those at the top, inequality rose as well. Not too long ago, the only data we had to judge the magnitude of these inequality trends were proxies, like the land rent to unskilled wage ratio or the GDP per worker to unskilled wage ratio (Williamson 1999, 2002). Thus, when the rent-wage ratios for Argentina, Mexico, Uruguay and Venezuela (Arroyo Abad 2008: Figure 1) are weighted by 1890 populations, the Latin American average rises 7.9 percent per decade $1850-1870$ and 6.3 percent per decade $1870-1900$, for a total increase of 37 percent after 1850 . This rent-wage proxy thus implies a big inequality surge over the second half of the century. We also have the more comprehensive belle époque 
inequality evidence for the Southern Cone summarized in Table 6. It comes from two sources: first, Ginis calculated from new evidence collected by Luis Bértola and his collaborators (2009: Table 4), and second, what Leandro Prados de la Escosura (2007: Table 12.1) calls his backward projected Pseudo-Ginis. They both tell the same tale: inequality rose by 11-37 percent over the belle époque. True, and as the table makes clear, the Latin American weighted average reported in Table 6 refers only to four republics in the Southern Cone - Argentina, Brazil, Chile and Uruguay. Thus, the average misses the heavily populated Mexican and Andean republics. However, Prados de la Escosura also shows that a Mexican inequality proxy -- income per worker to the unskilled wage ratio -- rose by about 2.8 times between the early 1880s and 1920 (Prados de la Escosura 2007: Figure 12.1b), suggesting that over its four Porfiriato prerevolutionary decades Mexico followed the Southern Cone by recording a steep rise in inequality. Brazil recorded a less spectacular increase between the early 1880s and the mid 1920s, but still the income per capita to unskilled wage ratio rose by about 45 percent (Prados de la Escosura 2007: Figure 12.1b). Furthermore, the Arroyo Abad rentwage inequality proxy for Mexico confirms the Prados data since the 1870-1900 increase was 27 percent over the three decades. Assuming, therefore, that Mexican inequality rose more like the Prados P-Ginis than the Bértola Ginis for the southern cone, it follows that Latin American inequality probably rose by something like 30 percent over the belle époque. Applying that increase to the 1870 Latin American Gini coefficient in Table 4 would imply that it rose from 46.4 to 60.3 , making the Gini in the 1920 s the highest that Latin America recorded since pre-conquest, even higher than the 1790 colonial peak (57.6), and much, much higher than 1600 (36.2). Any modern analyst who believes that 
high inequality has been an attribute of Latin America since the Iberian conquest should take note.

\section{Revisionist Hypotheses}

Figure 3 plots our inequality predictions from 1491 to 1929 . However crude the evidence may seem, it points to several revisionist interpretations of, or hypotheses about, 500 years of Latin American inequality.

First, it is simply not true that Latin America has always been unequal. It cannot be stressed enough that this is a comparative statement. Only by comparisons with other times and places can statements about Latin American inequality offer any useful meaning. While comparisons with the United States are not uncommon in the recent literature, comparisons with the European (colonial) leaders or with other parts of the poor periphery are rarely, if ever, made. When such comparisons are made (Table 3 and Milanovic, Lindert and Williamson 2008), income inequality in pre-industrial Latin America is found to have been lower than that of northwest Europe, not higher. To repeat, it is not true that pre-industrial Latin America (pre-1870) was more unequal than pre-industrial northwest Europe (pre-1800). Thus, if, as Engerman and Sokoloff have suggested, it is thought that inequality encouraged rent-seeking, suppressed private property rights, retarded the development of 'good' institutions, and thus discouraged growth in Latin America, it must have done even more so in northwest Europe where the industrial revolution first started! In addition, it appears that pre-conquest Latin America had one of the lowest, if not the lowest, level of inequality anywhere in the poor 
periphery. It also appears that Latin American inequality remained one of the lowest anywhere around the world until the start of the seventeenth century. It can hardly be said that initial endowments and Iberian colonization made Latin America more unequal than other places.

Second, Latin America was poorer than northwest Europe, and poorer societies have smaller surpluses for the elite to extract. Thus, while inequality was lower, what this paper and Milanovic et al. (2008) call extraction rates (how much of the available surplus was actually extracted by the elite) were considerably higher in Latin America than in northwest Europe. Whether measured inequality or extraction rates are the best indicators of pro-rent-seeking and anti-growth institutions is an issue that needs to be resolved since they offer very different inferences regarding Latin American growth underachievement. Presumably, political inequality had an important influence on the size of the extraction ratio.

Third, Latin American inequality over the five centuries from pre-conquest to the present has exhibited immense variance: indeed, Latin America exhibited more inequality variance between 1491 and 1929 (Ginis ranging from 22.5 to 60.3) than one can find across Latin America today (Ginis ranging from 42 for Trinidad and Tobago to 60 for Bolivia: López and Perry 2008: Figure 1, Panel A), or than one can between Latin America, Europe, and East Asia today $(51,34,38$, respectively: López and Perry 2008: 23). While the historical literature certainly offers strong opinions about potential explanations, we need far more evidence to document them firmly. By replacing less rapacious indigenous elite with more rapacious European elite, the Iberian conquest appears to have raised, initially, inequality by about half. Yet, the sixteenth century saw 
very little further rise in inequality, most probably because the demographic disaster produced a powerful downward offset to all other inequality-increasing forces. It looks like the two centuries up to about 1790 or so saw the biggest increase in Latin American inequality, reaching its colonial peak in that year (Gini 57.6: Table 4). What are the explanations for the colonial inequality boom? Was it simply driven by increases in GDP per capita and thus in the surplus available for the elite to extract? Or, did the elite learn more effective ways to extract a bigger share of the same surplus? Or was it both? In any case, about half of that huge rise up to 1790 was eroded by three decades of war and independence, followed by five post-independence 'lost decades' of economic stagnation. Thus, by 1870 inequality in Latin America (Gini 46.4: Table 4) was not much different than it was for all pre-industrial societies for which we can get the data (Gini 44.3: Table 1). To repeat, while inequality was high in Latin America as it was poised for its industrial revolution, it was no higher than the average pre-industrial society, nor higher than industrializing Europe.

Fourth, globalization forces during the belle époque pushed Latin American inequality up to historic highs by the 1920s. Although that belle époque inequality boom cannot yet be adequately measured for all of Latin America, it looks like ongoing research will shortly do so (e.g Bértola et al. 2009). Other primary product exporters underwent similar inequality-enhancing booms over that half century too (Williamson 2002; 2006), but it appears that Latin America had one of the biggest inequality booms, and, even more notable, that the high inequality achieved persisted (and even increased) during the anti-global episode between the 1920s and the 1970s (Prados 2007: Table 12.1). The latter offers a striking contrast with the industrialized world which underwent 
a great egalitarian leveling across the mid-20 ${ }^{\text {th }}$ century (Williamson and Lindert 1980 :

53-62; Goldin and Margo 1992; Atkinson and Piketty 2008).

The inequality history that makes Latin America distinctive stretches across the $20^{\text {th }}$ century when Europe and its English-speaking offshoots underwent a secular decline in inequality correlated with the rise of the welfare state (Lindert 2004; Atkinson and Piketty 2008). Latin America did not share that $20^{\text {th }}$ century decline. Why has $20^{\text {th }}$ century Latin American inequality history been so unique, while everything else about their inequality history from 1491 to the 1920 s was so ordinary? 


\section{References}

Acemoglu, D., S. Johnson, and J. Robinson (2001), "The colonial origins of comparative development," American Economic Review, 91, 5: 1369-1401.

Acemoglu, D., S. Johnson, and J. Robinson (2002), "Reversal of Fortune: Geography and Development in the Making of the Modern World Income Distribution," Quarterly Journal of Economics (4: 2002): 1231-94.

Acemoglu, D. and J. Robinson (2006), "De Facto Political Power and Institutional Persistence," American Economic Review 96(2): 325-30.

Arroyo Abad, L. (2008), "Inequality in Republican Latin America: Assessing the Effects of Factor Endowments and Trade," GPIH Working Paper 12, University of California, Davis (November 2008).

Atkinson, A. and T. Piketty (2008), Top Incomes Over the Twentieth Century: A Contrast Between Continental European and English-Speaking Countries (Oxford: Oxford University Press).

Bairoch, P. (1993), Economics and World History: Myths and Paradoxes, New York: Harvester Wheatsheaf.

Banerjee, A. and L. Iyer (2005), "History, Institutions and Economic Performance: the Legacy of Colonial Land Tenure Systems in India," American Economic Review 95(4): 1190-1213.

Barnett, G. E. (1936), Two Tracts by Gregory King, Baltimore: Johns Hopkins University Press. 
Bates, R. H., J. H. Coatsworth, and J. G. Williamson (2007), “Lost Decades:

Postindependence Performance in Latin America and Africa," Journal of Economic History 67 (December): 917-43.

Bértola, L. (2009), "Institutional Development and Long-Term Growth in Latin America," unpublished (July).

Bértola, L., C. Castelnovo, J. Rodríguez, and H. Willebald (2009), "Between the Colonial Heritage and the First Globalization Boom: On Income Inequality in the Southern Cone," paper presented to the $15^{\text {th }}$ World Economic History Congress (Utrecht, August 3-7).

Bruhn, M. and F. A. Gallego (2009), “Good, Bad, and Ugly Colonial Activities: Do They Matter for Economic Development," paper presented to the $15^{\text {th }}$ World Economic History Congress (Utrecht, August 3-7).

Campante, F. and Do, Q-A. (2007), “Inequality, Redistribution, and Population,” KSG Faculty Research Working Paper RWP07-046, Harvard University (October).

Chen, S. and M. Ravallion (2007), “Absolute Poverty Measures for the Developing World, 1981-2005,” World Bank Research Development Group, Washington, DC.

Clark, C. (1957), The Conditions of Economic Progress, $3^{\text {rd }}$ ed., London: Macmillan and Co.

Clingingsmith, D. and Williamson, J. G. (2008), "Deindustrialization in $18^{\text {th }}$ and $19^{\text {th }}$ century India: Mughal Decline, Climate Shocks and British Industrial Ascent," Explorations in Economic History 45 (July): 209-34. 
Coatsworth, J. H. (2008), "Inequality, Institutions and Economic Growth in Latin America," Journal of Latin American Studies 40 (August): 545-69.

Dobado, R. and H. Garcia (2009), "Neither so low nor so short! Wages and Heights in Eighteenth and Early Nineteenth Centuries Colonial Latin America," paper presented at the conference A Comparative Approach to Inequality and Development: Latin America and Europe, Madrid (May 8-9).

Engerman, S. and K. Sokoloff (1997), "Factor Endowments, Institutions, and Differential Paths of Growth Among New World Economies," in How Latin America Fell Behind, ed. by S. Haber, Palo Alto, Cal.: Stanford: 260-304.

Engerman, S., S. Haber and K. Sokoloff (2000), “Institutions, Factor Endowments, and Paths of Development in the New World," Journal of Economic Perspectives 14, 3: 217-32.

Goldin, C. and R. A. Margo (1992), "The Great Compression: The Wage Structure in the United States at Mid-Century," Quarterly Journal of Economics 107: 1-34.

Gelman, J. and D. Santilli (2006), Historia del Capitalismo agrario pampeano: Volume 3: De Rivadavia a Rosas; Desigualdad y crecimiento economico (Buenos Aires: Universidad de Belgrano-Siglo XXI).

Hoffman, P. T., D. Jacks, P. Levin, and P. H. Lindert, "Real Inequality in Western Europe since 1500,” Journal of Economic History 62, 2 (June 2002): 322-355. 
Johnson, L. L. and Z. Frank (2006), “Cities and Wealth in the South Atlantic: Buenos Aires and Rio de Janeiro before 1860," Comparative Studies in Society and History 48 (3): xx-xx.

Latham, A. J. H. and L. Neal (1983), "The International Market in Rice and Wheat 18681914," Economic History Review 36 (May): 260-75.

Lindert, P. H. (2004), Growing Public: Social Spending and Economic Growth Since the Eighteenth Century, Volume 1 (Cambridge: Cambridge University Press).

Lindert, P. H. and J. G. Williamson (1982), "Revising England's Social Tables, 16881812," Explorations in Economic History 19, 4: 385-408.

Livi-Bacci, M. (2006), "The Depopulation of Hispanic America after the Conquest," Population and Development Review 32 (June): 199-232.

López, J. H. and Perry, G. (2008), “Inequality in Latin America: Determinants and Consequences," Policy Research Working Paper 4504, The World Bank.

Maddison, A. (1998), Chinese Economic Performance in the Long Run, Paris: OECD Development Centre.

Maddison, A. (2008), at http://www.ggdc.net/Maddison

Milanovic, B., P. H. Lindert and J. G. Williamson (2008), “Ancient Inequality,” revised version of "Measuring Ancient Inequality," NBER Working Paper 13550, National Bureau of Economic Research, Cambridge, Mass. (October).

Mokyr, J. (1983), Why Ireland Starved: A Quantitative and Analytical History of the Irish Economy, 1800-1850, Boston: Allen and Unwin.

Nunn, N. (2008), "Slavery, Inequality, and Economic Development in the Americas: An 
Examination of the Engerman-Sokoloff Hypothesis," in E. Helpman (ed.), Institutions and Economic Performance (Cambridge, Mass.: Harvard University Press).

Prados de la Escosura, L. (2007), "Inequality and Poverty in Latin America: A Long-Run Exploration,” in T. J. Hatton, K. H. O'Rourke, and A. M. Taylor (eds.), The New Comparative Economic History (Cambridge, Mass.: MIT Press), pp. 291-315.

Prados de la Escosura, L. (2009), "Lost Decades? Economic Performance in PostIndependence Latin America," Journal of Latin American Studies 41 (2): forthcoming.

Ravallion, M., S. Chen and P. Sangraula (2007), "New evidence on the urbanization of global poverty," Population and Development Review 33, 4: 667701.

Studer, R. (2008), "India and the Great Divergence: Assessing the Efficiency of Grain Markets in Eighteenth- and Nineteenth-Century India," Journal of Economic History 68 (June): 393-437.

Williamson, J. G. (1999), "Real Wages, Inequality, and Globalization in Latin America Before 1940," Revista de Historia Economica 17, special number: 101-42.

Williamson, J. G. (2002), “Land, Labor, and Globalization in the Third World, 18701940," Journal of Economic History 62 (1): 55-85.

Williamson, J. G. (2006), Globalization and the Poor Periphery before 1950 (Cambridge, Mass.: MIT Press).

Williamson, J. G. (2008), “Globalization and the Great Divergence: Terms of Trade 
Booms and Volatility in the Poor Periphery 1782-1913," European Review of Economic History 12 (December): 355-91.

Williamson, J. G. (2009), Trade and Poverty since 1750: When the Third World Fell Behind (ongoing).

Williamson, J. G. and P. H. Lindert (1980), American Inequality: A Macroeconomic History (New York: Academic Press).

Young, A. (2005), "The Gift of the Dying: The Tragedy of AIDs and the Welfare of Future African Generations," Quarterly Journal of Economics 120 (May): 42366. 
Table 1 Pre-Industrial Inequality Measures

\begin{tabular}{|c|c|c|c|c|}
\hline Country/Region, Year & Gini & $\begin{array}{c}\text { Mean income } / \\
\mathrm{s}=\text { subsistence } \\
(\mathrm{s}=\mathbf{\$ 3 0 0})\end{array}$ & $\begin{array}{c}\text { Maximum } \\
\text { feasible Gini } \\
\text { (IPF) }\end{array}$ & $\begin{array}{l}\text { Inequality } \\
\text { extraction } \\
\text { ratio (in \%) }\end{array}$ \\
\hline Roman Empire 14 & 39.4 & 2.1 & 52.6 & 75.0 \\
\hline Byzantium 1000 & 41.1 & 1.8 & 43.7 & 94.1 \\
\hline England \& Wales 1290 & 36.7 & 2.1 & 53.0 & 69.2 \\
\hline Tuscany 1427 & 46.1 & 3.3 & 69.3 & 66.6 \\
\hline South Serbia 1455 & 20.9 & 1.5 & 32.2 & 64.8 \\
\hline Holland 1561 & 56.0 & 3.8 & 73.4 & 76.3 \\
\hline Levant 1596 & 39.8 & 3.2 & 69.1 & 57.6 \\
\hline England \& Wales 1688 & 45.0 & 4.7 & 78.8 & 57.1 \\
\hline Holland 1732 & 61.1 & 6.8 & 85.2 & 71.7 \\
\hline Moghul India 1750 & 48.9 & 1.8 & 43.4 & 112.8 \\
\hline Old Castille 1752 & 52.5 & 2.5 & 59.7 & 88.0 \\
\hline England \& Wales 1759 & 45.9 & 5.9 & 82.9 & 55.4 \\
\hline France 1788 & 55.9 & 3.8 & 73.5 & 76.1 \\
\hline Nueva España 1790 & 63.5 & 2.5 & 60.2 & 105.5 \\
\hline England \& Wales 1801 & 51.5 & 6.7 & 85.0 & 60.6 \\
\hline Bihar (India) 1807 & 33.5 & 1.8 & 43.7 & 76.7 \\
\hline Netherlands 1808 & 57.0 & 6.0 & 83.3 & 68.5 \\
\hline Naples 1811 & 28.4 & 2.2 & 52.9 & 53.7 \\
\hline Chile1861 & 63.7 & 4.3 & 76.8 & 83.0 \\
\hline Brazil 1872 & 43.3 & 2.4 & 58.3 & 74.2 \\
\hline Peru 1876 & 42.2 & 2.2 & 54.0 & 78.1 \\
\hline Java 1880 & 39.7 & 2.2 & 54.6 & 72.8 \\
\hline China 1880 & 24.5 & 1.8 & 44.4 & 55.2 \\
\hline Japan 1886 & 39.5 & 3.1 & 67.2 & 58.8 \\
\hline Kenya 1914 & 33.2 & 1.5 & 34.2 & 96.8 \\
\hline Java 1924 & 32.1 & 3.0 & 66.9 & 48.0 \\
\hline Kenya 1927 & 46.2 & 1.9 & 46.2 & 100.0 \\
\hline Siam 1929 & 48.5 & 2.6 & 62.1 & 78.1 \\
\hline British India 1947 & 49.7 & 2.1 & 51.3 & 96.8 \\
\hline Average & 44.3 & 3.1 & 60.6 & 74.9 \\
\hline \multicolumn{5}{|l|}{ Modern counterparts } \\
\hline Italy 2000 & 35.9 & 62.5 & 98.3 & 36.5 \\
\hline Turkey 2003 & 43.6 & 22.0 & 95.4 & 45.7 \\
\hline United Kingdom 1999 & 37.4 & 66.1 & 98.4 & 38.0 \\
\hline Serbia 2003 & 32.2 & 11.2 & 91.0 & 35.4 \\
\hline Netherlands 1999 & 28.1 & 72.0 & 98.5 & 28.5 \\
\hline India 2004 & 32.6 & 6.4 & 84.2 & 38.7 \\
\hline Spain 2000 & 33.0 & 50.9 & 97.9 & 33.7 \\
\hline France 2000 & 31.2 & 69.4 & 98.4 & 31.7 \\
\hline Mexico 2000 & 53.8 & 24.1 & 95.7 & 56.2 \\
\hline Chile 2003 & 54.6 & 33.7 & 96.6 & 56.4 \\
\hline Brazil 2002 & 58.8 & 13.9 & 92.7 & 63.4 \\
\hline Peru 2002 & 52.0 & 12.3 & 91.8 & 56.7 \\
\hline Kenya 1998 & 44.4 & 4.5 & 77.6 & 57.2 \\
\hline Indonesia 2002 & 34.3 & 10.7 & 90.5 & 37.9 \\
\hline China 2001 & 41.6 & 11.5 & 91.2 & 45.6 \\
\hline Japan 2002 & 26.0 & 70.2 & 98.5 & 26.4 \\
\hline Thailand 2002 & 50.9 & 21.3 & 95.2 & 53.5 \\
\hline Average & 40.6 & 33.1 & 93.6 & 43.6 \\
\hline
\end{tabular}




\begin{tabular}{lcccc}
\hline Country/Region, Year & Gini & $\begin{array}{c}\text { Mean income/ } \\
\text { s=subsistence } \\
\text { (s=\$300) }\end{array}$ & $\begin{array}{c}\text { Maximum } \\
\text { feasible Gini } \\
\text { (IPF) }\end{array}$ & $\begin{array}{c}\text { Inequality } \\
\text { extraction } \\
\text { ratio (in \%) }\end{array}$ \\
\hline countries & & & \\
\hline South Africa 2000 & 57.3 & 14.7 & 93.1 & 61.6 \\
United States 2000 & 39.9 & 77.7 & 98.6 & 40.5 \\
Sweden 2000 & 27.3 & 52.2 & 98.0 & 27.9 \\
Germany 2000 & 30.3 & 62.0 & 98.3 & 30.8 \\
Nigeria 2003 & 42.1 & 3.0 & 66.7 & 63.1 \\
Congo, D.R., 2004 & 41.0 & 1.5 & 33.3 & 123.1 \\
Tanzania 2000 & 34.6 & 1.8 & 44.4 & 77.9 \\
Malaysia 2001 & 47.9 & 26.0 & 96.1 & 49.9 \\
Source: Milanovic, Lindert and Williamson (2008: Table 2). Ancient societies ranked by year.
\end{tabular}


Table 2 Regression Results for the Gini Coefficient

\begin{tabular}{|c|c|c|c|}
\hline GDP per capita & $\begin{array}{c}360.5^{* * *} \\
(0.001)\end{array}$ & $\begin{array}{c}366.7^{* * *} \\
(0.001)\end{array}$ & $\begin{array}{c}360.2^{* * *} \\
(0.002)\end{array}$ \\
\hline GDP per capita squared & $\begin{array}{c}-25.0^{* * *} \\
(0.002)\end{array}$ & $\begin{array}{l}-25.5^{\star * *} \\
(0.002)\end{array}$ & $\begin{array}{c}-25.0^{* * *} \\
(0.003)\end{array}$ \\
\hline Urbanization rate & $\begin{array}{l}0.349^{*} \\
(0.08)\end{array}$ & $\begin{array}{l}0.354^{*} \\
(0.08)\end{array}$ & $\begin{array}{l}0.353^{*} \\
(0.093)\end{array}$ \\
\hline Population density & $\begin{array}{c}-0.105^{\star * *} \\
(0.001)\end{array}$ & $\begin{array}{c}-0.100^{* * *} \\
(0.003)\end{array}$ & $\begin{array}{l}-0.107^{*} \\
(0.053)\end{array}$ \\
\hline Number of groups & $\begin{array}{c}-0.009 \\
(0.16)\end{array}$ & $\begin{array}{r}-0.009 \\
(0.19)\end{array}$ & $\begin{array}{r}-0.010 \\
(0.18)\end{array}$ \\
\hline Colony (0-1) & $\begin{array}{c}12.63^{* * *} \\
(0.001)\end{array}$ & $\begin{array}{c}12.93^{\star * *} \\
(0.001)\end{array}$ & $\begin{array}{c}12.41^{* * *} \\
(0.002)\end{array}$ \\
\hline Foreigner $(0-1)$ & $\begin{array}{l}-9.59 \\
(0.25)\end{array}$ & $\begin{array}{l}-9.97 \\
(0.25)\end{array}$ & $\begin{array}{l}-9.26 \\
(0.29)\end{array}$ \\
\hline Asia (0-1) & & $\begin{array}{l}-1.28 \\
(0.69)\end{array}$ & \\
\hline Tax survey $(0-1)$ & $\begin{array}{l}-4.86 \\
(0.57)\end{array}$ & $\begin{array}{l}-4.85 \\
(0.24)\end{array}$ & $\begin{array}{l}-4.85 \\
(0.28)\end{array}$ \\
\hline Constant & $\begin{array}{c}-1246^{* * *} \\
(0.001)\end{array}$ & $\begin{array}{c}-1266^{* * *} \\
(0.001)\end{array}$ & $\begin{array}{c}-1245^{\star * *} \\
(0.002)\end{array}$ \\
\hline Number observations & 28 & 28 & 26 \\
\hline Adjusted R squared & 0.75 & 0.73 & 0.73 \\
\hline
\end{tabular}

Notes: GDP per capita is in natural logs. Coefficients significant at 10, 5 and 1 percent level denoted by respectively three, two and one asterisks, $\mathrm{p}$ values between brackets.

Source: Milanovic, Lindert and Williamson 2008: Table 3). 
Table 3 Inequality in Pre-Industrial Latin America and Western Europe Compared

\begin{tabular}{|c|c|c|c|c|c|c|c|c|}
\hline Country & Year & $\begin{array}{c}\text { Source of } \\
\text { Income Data }\end{array}$ & Population & $\begin{array}{c}\text { Urbanization } \\
\text { Ratio (\%) }\end{array}$ & $\begin{array}{l}\text { Ratio Peasant } \\
\text { to Mean } \\
\text { Income }\end{array}$ & $\begin{array}{l}\text { Actual } \\
\text { Gini }\end{array}$ & $\begin{array}{l}\text { Maximum } \\
\text { Feasible } \\
\text { Gini }\end{array}$ & $\begin{array}{c}\text { Extraction } \\
\text { Ratio }\end{array}$ \\
\hline Brazil & 1872 & occupational census & 10,167 & 16.2 & 0.67 & 43.3 & 58.3 & 0.743 \\
\hline Chile & 1861 & occupational census & 1,702 & 29 & 0.28 & 63.7 & 76.8 & 0.829 \\
\hline Nueva España & 1790 & social tables & 4,500 & 9.1 & 0.24 & 63.5 & 60.5 & 1.052 \\
\hline Peru & 1856 & social tables & 2,469 & 15 & & 35.5 & 54.0 & 0.657 \\
\hline $\begin{array}{l}\text { Latin America } \\
\text { Unweighted }\end{array}$ & & & 18,838 & & & & & \\
\hline average & & & & 17.3 & 0.40 & 51.5 & 62.4 & 0.825 \\
\hline Weighted average & & & & 15.5 & 0.51 & 48.9 & 59.9 & 0.816 \\
\hline England & 1688 & social tables & 5,700 & 13 & 0.21 & 45.0 & 78.8 & 0.571 \\
\hline England & 1759 & social tables & 6,463 & 16 & 0.37 & 45.9 & 82.9 & 0.554 \\
\hline England & 1801 & social tables & 9,053 & 30 & 0.34 & 51.5 & 85.0 & 0.606 \\
\hline France & 1788 & $\begin{array}{l}\text { social tables } \\
\text { tax census dwelling }\end{array}$ & 27,970 & 12 & 0.27 & 55.9 & 73.5 & 0.761 \\
\hline Holland & 1561 & $\begin{array}{l}\text { rents } \\
\text { tax census dwelling }\end{array}$ & 983 & 45 & & 56.0 & 73.4 & 0.766 \\
\hline Holland & 1732 & rents & 2,023 & 39 & & 61.1 & 85.2 & 0.717 \\
\hline $\begin{array}{l}\text { Western Europe } \\
\text { Unweighted }\end{array}$ & & & 52,192 & & & & & \\
\hline average & & & & 25.8 & 0.30 & 52.6 & 79.8 & 0.659 \\
\hline Weighted average & & & & 17.4 & 0.29 & 52.9 & 77.7 & 0.681 \\
\hline
\end{tabular}

Source: Milanovic, Lindert, and Williamson (2008). 
Table 4 Data used for the Gini Predictions and the Ginis

$\begin{array}{ccccc}\begin{array}{c}\text { GDP } \\ \text { per capita }\end{array} & \begin{array}{c}\text { Urbanization } \\ \text { Rate (\%) }\end{array} & \begin{array}{c}\text { Colony } \\ \text { Dummy }\end{array} & \begin{array}{c}\text { Density } \\ \text { (person/km2) }\end{array} & \begin{array}{c}\text { Gini Coefficients } \\ \text { Actual Predicted }\end{array} \\ \text { US\$) } & & & & \\ \text { US } & & & & \end{array}$

\begin{tabular}{|c|c|c|c|c|c|c|c|}
\hline \multicolumn{8}{|c|}{ Latin America } \\
\hline \multicolumn{2}{|c|}{1491} & 416 & 11.0 & 0 & 1.60 & & 22.5 \\
\hline \multicolumn{2}{|c|}{1492} & 416 & 11.0 & 1 & 1.60 & & 35.1 \\
\hline \multicolumn{2}{|c|}{1600} & 438 & 9.0 & 1 & 0.78 & & 36.2 \\
\hline \multicolumn{2}{|c|}{1700} & 530 & 12.5 & 1 & 1.10 & & 48.5 \\
\hline \multicolumn{2}{|c|}{1790} & 650 & 14.2 & 1 & 1.14 & & 57.6 \\
\hline \multicolumn{2}{|c|}{1820} & 691 & 13.9 & 0 & 1.97 & & 47.0 \\
\hline \multicolumn{2}{|c|}{1870} & 676 & 15.0 & 0 & 3.68 & & 46.4 \\
\hline \multirow[t]{4}{*}{ Mexico } & 1790 & 710 & 9.1 & 1 & 4.96 & 63.5 & 57.7 \\
\hline & 1820 & 759 & 8.9 & 0 & 5.38 & & 47.8 \\
\hline & 1844 & 718 & 9.2 & 0 & 6.41 & 51 & 46.1 \\
\hline & 1870 & 674 & 9.6 & 0 & 7.41 & & 44.0 \\
\hline Brazil & 1872 & 721 & 16.2 & 0 & 1.20 & 43.3 & 48.9 \\
\hline Chile & 1861 & 1083 & 29.0 & 0 & 2.23 & 63.7 & 72.3 \\
\hline Peru & 1876 & 653 & 15.0 & 0 & 1.92 & 42.2 & 45.4 \\
\hline
\end{tabular}

\section{Sources and Notes:}

GDP per capita: Maddison (2008), except Peru 1876 from Milanovic, Lindert and

Williamson (2008: Table 1). For Latin America, Mexico and Brazil, 1790 is linearly interpolated between 1700 and 1820. For Chile1790, the Mexican growth rate 1790-1820 is assumed.

Population: Maddison (2008). Missing years linearly interpolated.

Urbanization: Bairoch (pp. 388-9, 423) and Sánchez-Albornoz (1974: pp. 30-32, 77). Latin American 1820 interpolated. Mexico 1820 and 1870 derived by assuming percent fall 17901820

and rise 1820-1870 the same as for Latin America.

Land area: Milanovic, Lindert and Williamson (2008: Table 1).

Colony dummy: While Chile gained independence in 1818, the other did so shortly after 1820:

Brazil 1822, Mexico 1821, Peru 1821, and a few even later. Yet, the colony dummy is still set equal to 0 in 1820 for Latin America and all four regions in the table.

Actual Gini: Tables 1 and 3.

Predicted Gini: Data above inserted in to estimated regression, col. 1, Table 2. 
Table 5. An Inequality Proxy for Central Mexico:

Hacienda Land Rents per hectare Relative to City Unskilled Wages 1780-1869

$\begin{array}{rc}\text { Decade } & \begin{array}{c}\text { Land rent/unskilled wage } \\ 1800-09=100\end{array} \\ 1780-1789 & 62.0 \\ 1790-1799 & 72.5 \\ 1800-1809 & 100.0 \\ 1810-1819 & 80.5 \\ 1820-1829 & 71.0 \\ 1830-1839 & 77.3 \\ 1840-1849 & 78.6 \\ 1850-1859 & 60.8 \\ 1860-1869 & 52.6\end{array}$

Sources: Land rents are constructed from data taken from personal correspondence from Amilcar Challu, who collected the central Mexican hacienda data from secondary sources. Land rent is assumed to trend as did land values since documents suggest that lan

Table 6. Southern Cone Inequality Trends 1870-1920s

\begin{tabular}{|c|c|c|c|c|c|c|c|c|c|c|}
\hline & \multicolumn{2}{|c|}{ Argentina } & \multicolumn{2}{|c|}{ Brazil } & \multicolumn{2}{|c|}{ Chile } & \multicolumn{2}{|c|}{ Uruguay } & \multicolumn{2}{|c|}{ Latin America } \\
\hline & Gini & P-Gini & Gini & P-Gini & Gini & P-Gini & Gini & P-Gini & Gini & P-Gini \\
\hline 1870 & 52.2 & 39.1 & 53.4 & 32.9 & 59.4 & 41.3 & 48.1 & 29.6 & 53.7 & 34.8 \\
\hline 1920s & 57.4 & 49.3 & 59.7 & 47.2 & 64.1 & 49.2 & 56.2 & 36.6 & 59.6 & 47.5 \\
\hline$\%$ change & 10.0 & 26.1 & 11.8 & 43.5 & 7.9 & 19.1 & 16.8 & 23.6 & 11.0 & 36.5 \\
\hline
\end{tabular}

Sources: Ginis for 1870 and 1920 from Bértola et al. (2009: Table 4). Pseudo-Ginis for 1870 and 1929, from Prados (2007: Table 12.1).

Notes: The Latin America weighted Gini averages use 1900 population as weights. The P-Gini is a Pseudo-Gini derived from backward projection. See Prados de la Escosura (2007: Table 12.2). 


\section{Figure 1 Ancient Inequalities: Estimated Gini Coefficients, and the Inequality Possibility Frontiers}

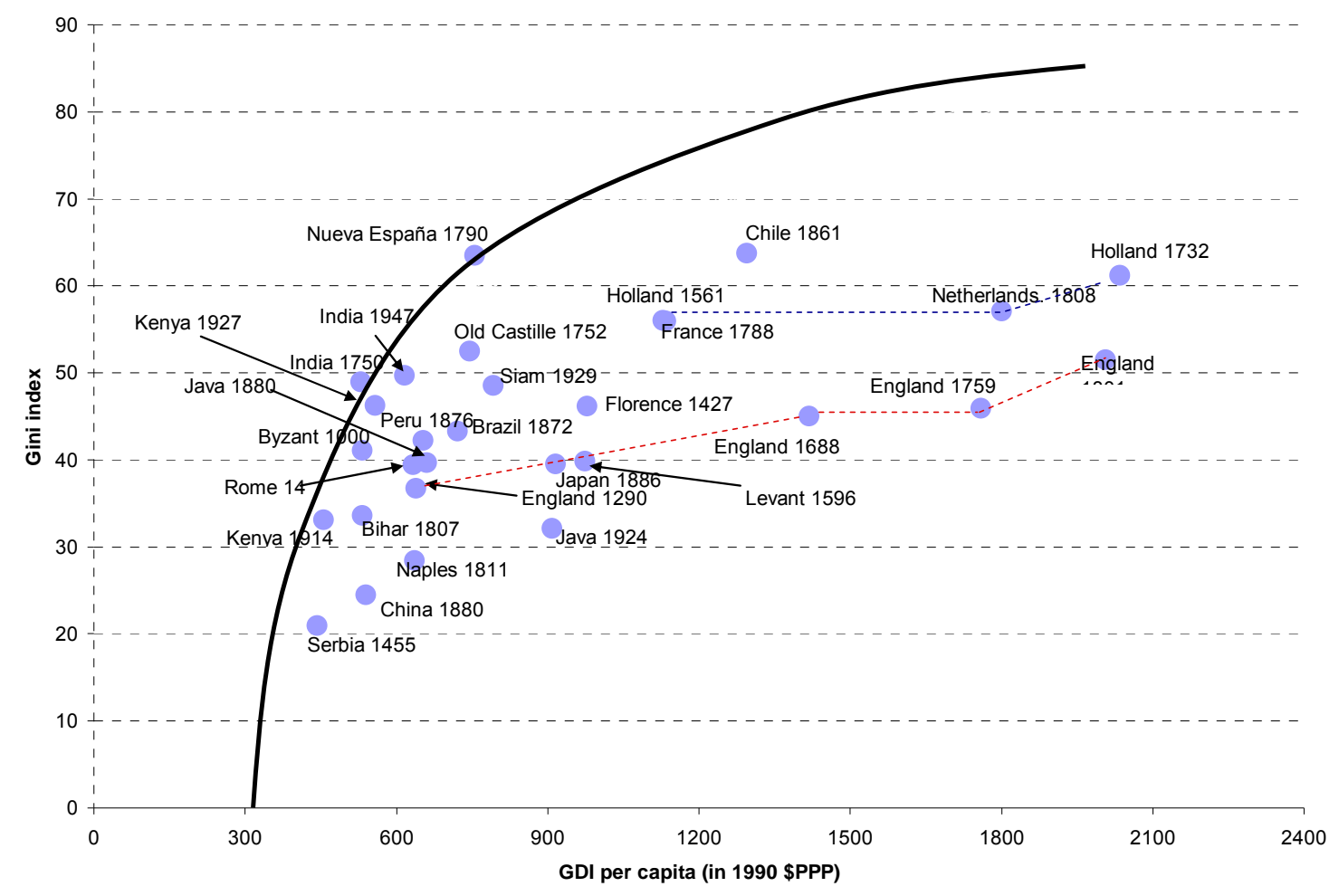

Note: The solid line IPF is constructed on the assumption that $\mathrm{s}=\$ P P P 300$. See text. Source: Milanovic, Lindert and Williamson (2008: Figure 2). 
Figure 2

Inequality Extraction Ratio for the Ancient Society Sample and their Counterpart Modern Societies

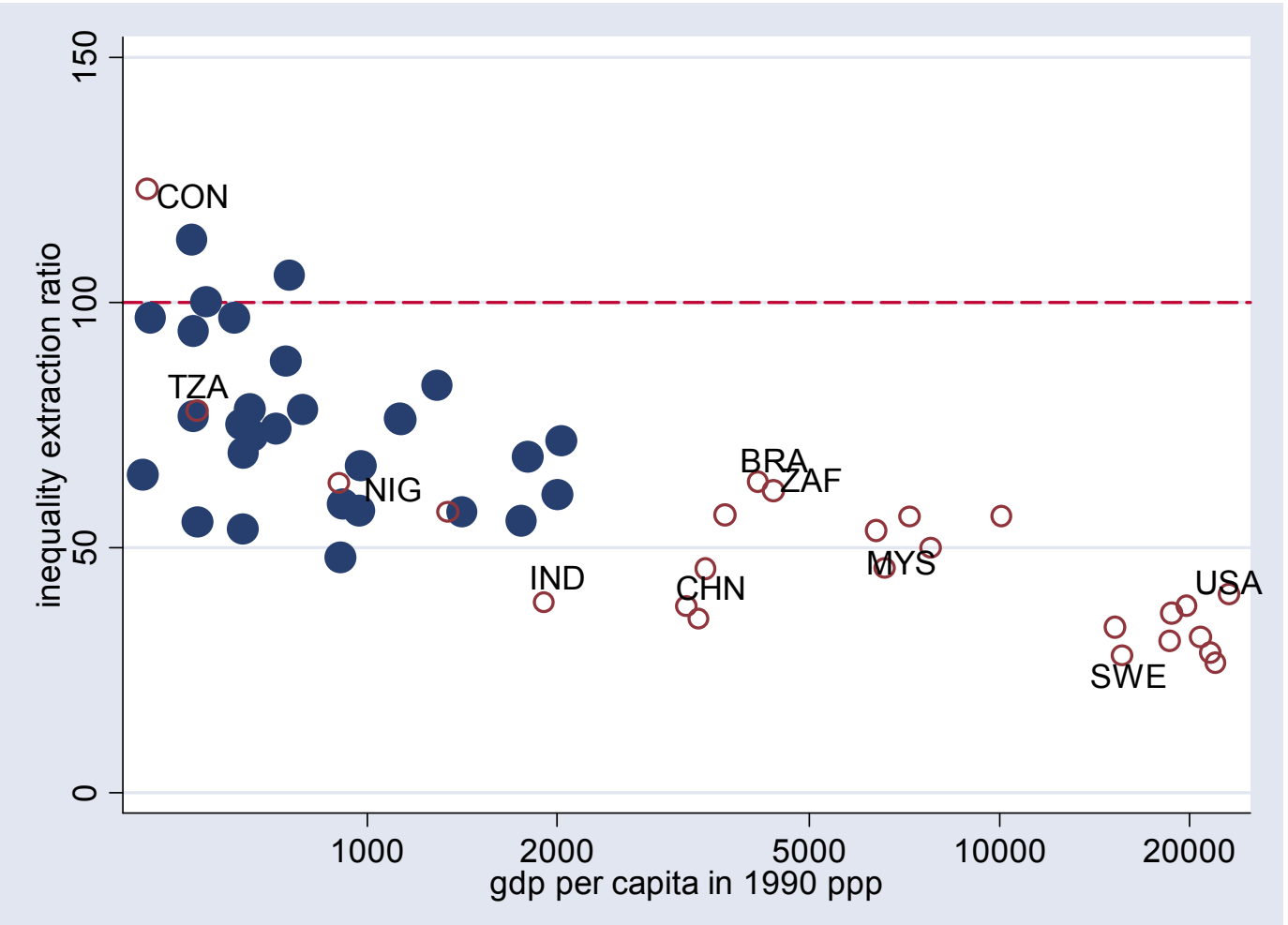

Note: Modern societies are drawn with hollow circles. Horizontal axis in logs. Inequality extraction ratio shown in percentages.

Source: Milanovic, Lindert and Williamson (2008: Figure 4). 
Figure 3. Likely Inequality Trends in Latin America 1491-1929

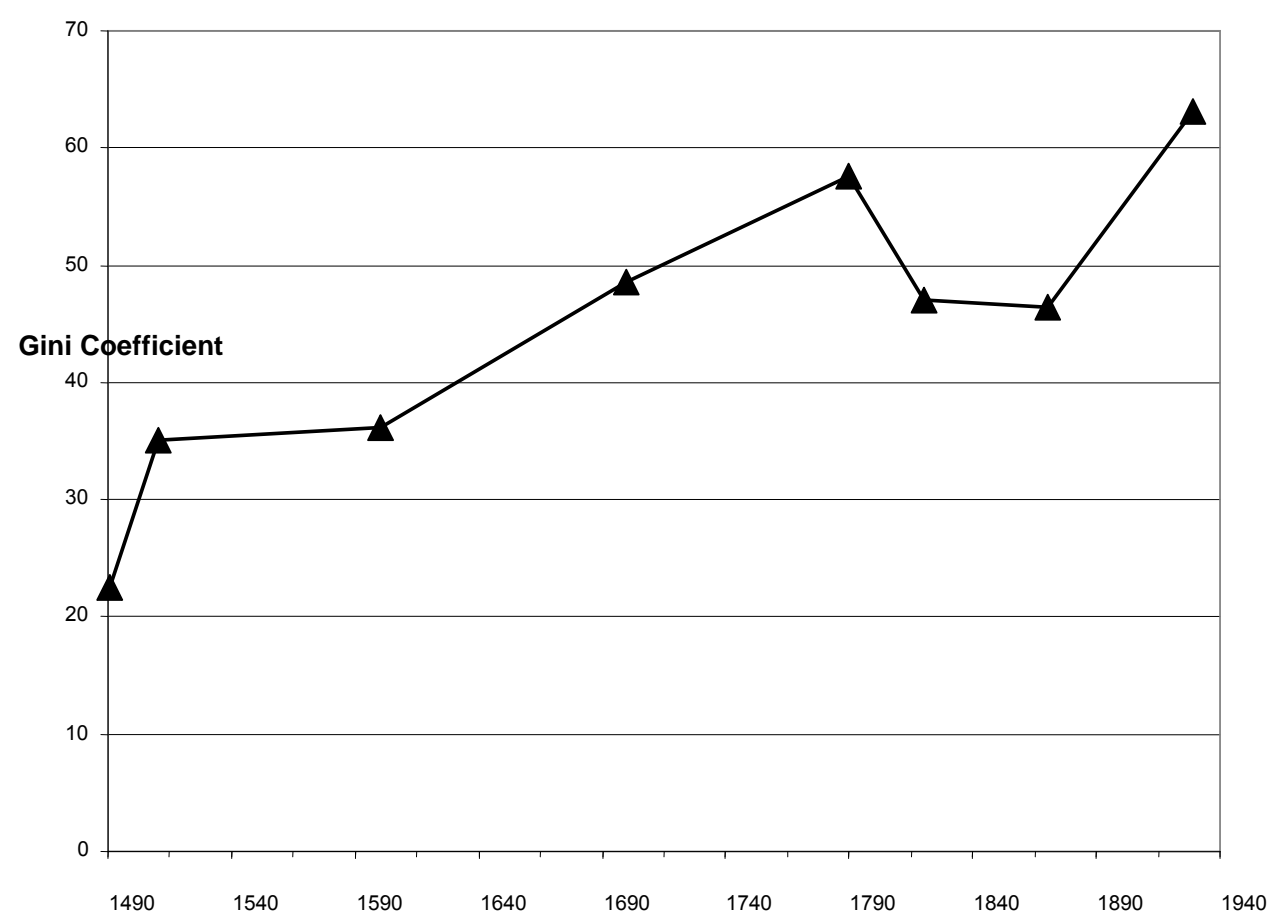

